\title{
-Session 2-
}

\section{肺線維症の形成における基底膜の役割}

一一水腫性变化の持続を中心として——

鳥 潟 親 雄* 竹 内

はじめに

実験的に，動物肺に diffuse fibrosis を創りだ すことは容易なことではない，文献上でも抗癌 剂を含む薬物の投与, 酸素を含むガスの吸引, 放射線照射, および免疫学的手法を用いた肺病 変の報告がみられるにすぎない，これらの報告 例も, われわれが剖検肺で観る人肺の線維化巣 とは, その病変の程度, 分布に大きな差が認め られ, 外来刺激に対する蔵器としての肺の反応 形態に，人扣よび実験動物間にかなりの差違の あることが推察される，さらに，肺線維化の機 序, 就中, 病変の不可逆性を決定する因子に関 しては，まったく分っていない状況である。

実験的間質性肺炎または肺線維症において， 免疫学的手法を用いた報告には, nephrotoxic antibody 等を投与した時1)に，たまたま認め られる肺変化と, 他方, Dixon, ${ }^{2)}$, 北村 ${ }^{3)}$ らに よる抗肺抗体投与による肺病変の報告である. 後者の場合に抢いても, 肺以外の蔵器に病変が 認められることがあり，特に腎病変を合併する ものは, Goodpasture 症候群類似のものとして 報告されている4).

われわれは牛血清アルブミン（BSA）を抗原 に用い, 抗 BSA 家鬼血清との間に可溶性 抗原 抗体複合物（sol.1. c) を作成し，これをモルモ ットに投与することにより生起される血管を 中心とする形態変化について, 報告5) してきた が，今回，これらの動物を正常肺に対しては subtoxic とされる高酸素下で, 連続飼育するこ とにより以前より認めていた，間質性肺炎をさ

* 慶応義塾大学医学部病理

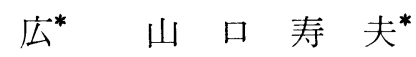

らに進行させ，人間のそれにかなり類 似した diffuse fibrosis を高頻度に創り出すことができ た. room air 中で飼育した場合には, room air 間質性肺炎の像にとどまり，しかも，時間の経 過とともに，ほぼ完全に治癒する病変を高酸素 吸入により遷延化し，線維化まで導く要因はな んであろらか. 電子顕微鏡を用いた検索を中心 に形態面から追求した.

\section{I. 実験方法}

BSA で成熟家鬼を免疫し，抗 BSA 家鬼血清 を準備する。抗 BSA 家鬼血清に最適比の 10倍 量の抗原 (BSA) を加え, sol 1.c. を作成し, こ の $1.0 \mathrm{~m} l$ をモルモット耳静脈より 1 回注射し, 以後, 連続的に高酸素環境下 (酸素濃度, 40 $60 \% ， 1$ 気圧）で飼育する，4 カ月まで経時的 に屠殺し, 光顕並びに電顕的に観察した.

電顕材料は, $1 \% \mathrm{O}_{5} \mathrm{D}_{4}$ で 2 時間固定後, 脱 水, Epon 包埋を行い, 超薄切片は, 鉛扣よび ウラニウムの重染色を施し観察した.

なお, sol 1.c. を静注し room air 中で飼育し たもの，および無処置モルモットを同条件の高 酸素下で長期にわたり飼育し, 同様方法を用い 検索した。

光顕材料は, $10 \%$ formalin で固定後 paraffin に包埋, 切片は H-E 染色, 必要に応じ, 特殊 染色を行い観察した。

\section{II. 実験結果}

高酸素下で飼育した無処置モルモット肺に は, 形態上, 顕著な変化は認められない。

Sol. l.c. を静注し， room air 中で 飼育した 動物肺には, 注射後数日から, 間質性肺炎が必 


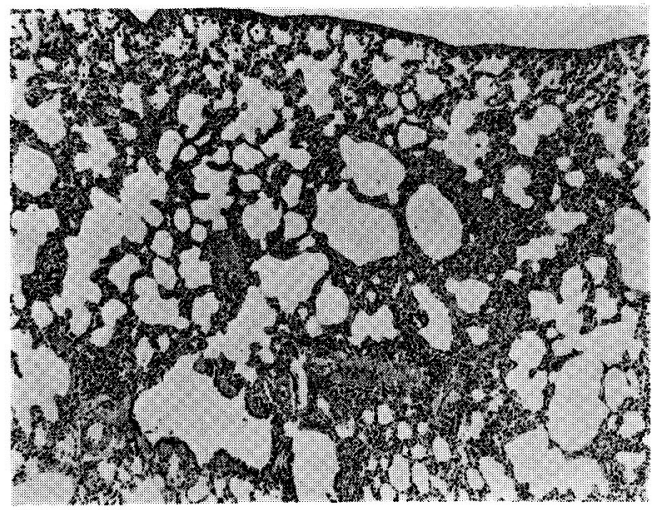

図1100日目，モルモット肺

肺胞壁の濔慢性線維性肥厚 ( $\mathrm{H}-\mathbf{E} ， 70$ 倍)

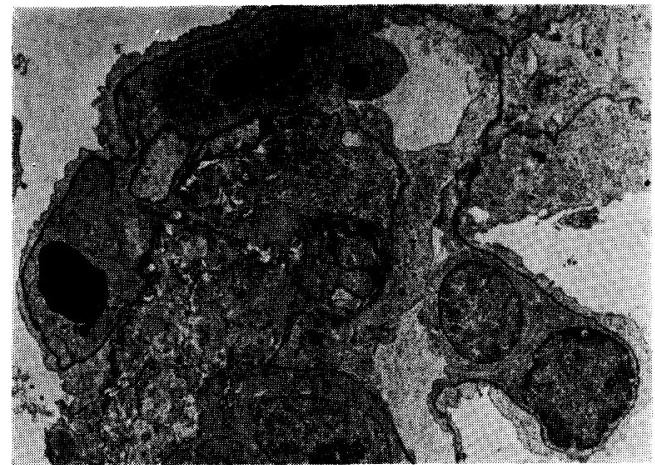

図 310 日目モルモット肺

基底膜の肥厚扣よび電子密度の增加，間質に お汀万間質細胞の賦活（3,000倍）

発してくるが， $3 〜 4$ 週後には，治癒傾向を示 し，最終的には，形態的変化をほとんど残さず に注㜔完に治痖する。電顕上でも，基底膜に 特別な変化は認められない。

sol. l.c. を静注し，高酸素下で 飼育した動物 肺には，3〜 5 日後，著明な肺胞壁の浮腫を認 め，それにひき続いて，間質の細胞増生による 肺胞壁の肥厚が認められ，いわゆる間質性肺炎 の像を示す。これらの動物では治瘜傾向も示さ ず，病変は遷延化し，かつ進行性で，50～70日 後には高頻度に diffuse fibrosis が認められる

（図 1 ）。ささらに，100日を超觉る動物肺には， いわゆる adenomatous hyperplasia の像がしば しば認められる。

電顕的観察で，もっとも顕著な差は基底膜に

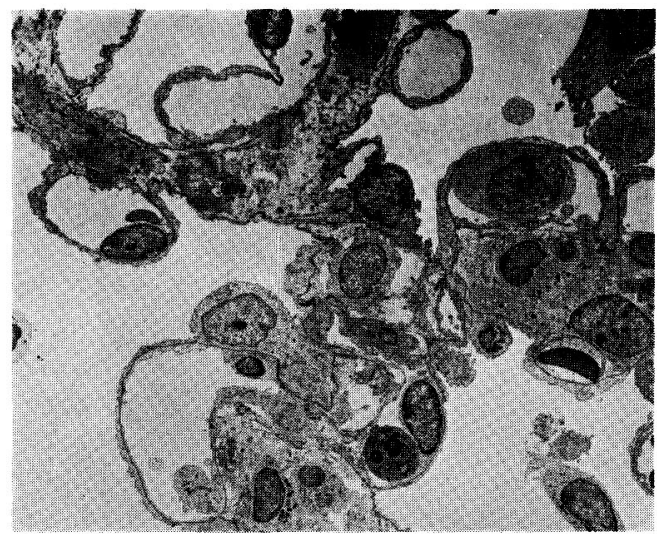

図 25 日目モルモット肺。

肺胞道拉よび肺胞壁の水腫性卒化基底膜の電 子密度の增加（1,300倍）

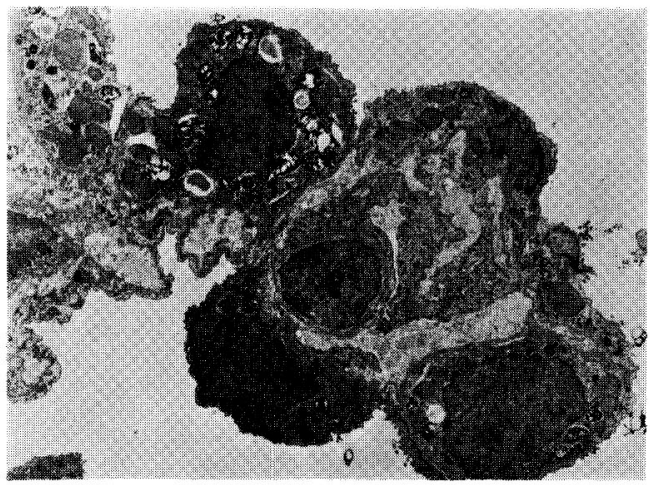

図 4100日目モルモット肺

肺胞壁の線維性肥厚毛細血管は新生された膠 原線維中に埋没。肺胞上皮では型上皮細胞が 目立つ $(3,600$ 倍 $)$

認められる。すなわち $3 \sim 5$ 日目の間質の水腫 性変化が顕著になってくる頃より，毛細血管内 皮下及び肺胞上皮下の基底膜が， diffuse に肥厚 し，電子密度が高くなり，正常基底膜に認めら れる三層構造が不明瞭になってくる（図2,3).

この変化は, 間質の線維化が完成するまで持続 する。水腫性に, 肥厚した間質に, いわゆる septal cell が増生し，7〜10 日で間質性肺炎の 像を呈してくる，その像は，これらの変化に加 えて, 膠原線維の新生が，著明となり， blood一 air barrier の構造上の破壊が起こってくる，か くして, 肺胞壁に和ける毛細血管は, 膠原線維 間に埋め込まれ，かつ，血管腔の減少が認めら 
れる（図 4 ）。

この間，毛細血管内皮には，すでに報告した ような内皮細胞の腫大, 空胞化, arcade formation, 基底膜からの部分的な剝離等の形態变化 が認められる。

肺胞上皮では, 型上皮が著明に障害され, 腫 脹, 変性, 脱落がみられ, alveolar ulcer の形 成も認められる。II 型上皮は, ⿷とんど, 障害 されることなく，むしろ， reserve cell として の機能を示し, 分裂, 増殖し, 脱落した I 型上 皮の跡を埋めて肺胞上皮の大部分を占めるよう になる。かくして，肺胞上皮では，II 型上皮が 優位を占め, 間質は, 線維性に肥厚し, 減少し た肺毛細血管が，これら間質中に埋め込まれ肺 胞壁構造の改築をともなった線維化巣ができあ がる.

\section{III. 考按}

基底膜の機能に関しては, 多くの報告がある が, そのもっとも重要なものは, filter として の作用であろう。

基底膜の病的形態変化としては, 物質の沈着 と多層化 (lamellation) が報告されているが， この実験では多層化の所見は得られていない。

実験的肺線維症や肺水腫の電顕的観察の報告 はあるが，今回認められたような変化の報告は ない，また，基底膜の構造と機能の維持のため には, 特異な間葉系細胞の参画が必要とされて いるが6), 今回の観察でも, 線維化の完成した 場所の毛細血管周囲に周細胞様のものを認める ことが多く興味ある所見である。

今回認められた基底膜の変化は, sol. 1. c. の 沈着だけとは, 形態所見等から考え難く、 ま た，高酸素による基底膜自体の変性の結果とも 考えられない. sol. 1. c. と高酸素の相互作用に 基づく基底膜の形態異常であるが，その本態に 関しては，な拉不詳である。しかしながら，こ の変化が, 肺胞間質に貯留した滲出物の排除を 妨害し，水腫の持続を招来し，ために，炎症性 変化の遷延化を原因したことは十分考兄られる ことである.

今回用いた $40 〜 60 \%$ の酸素濃度は, 哺乳類の
肺に対しては, subtoxic とされている範囲7) 内 のものであり, 事実, この条件下で飼育した無 処置モルモットに酸素中毒等の変化を見い出し えなかったことは，健康モルモット肺に対して は，この濃度に拈ける酸素自体の障害作用はな いと考觉てよいと思われる。

しかしながら， sol. 1. c. を投与した動物に対 しては, 強く障害性に作用し, diffuse fibrosis に導びく大きな要因となっていることも事実で ある。

健常肺に対する純酸素の障害性に関しては, 一致した見解が示されているが，高酸素の安全 性の限界に関しては, 現在, な拈, 種々の報告 があり，一致した見解は示されていない。さら に, 今回の結果からも, 病的肺に関しては, 別 の観点からその安全性の限界を検討する必要が あると考える.

なお，動物肺に执いては，人肺にみられるよ らな肺胞内滲出物の器質化による線維化巣の形 成はほとんど認められない。

\section{文 献}

1) Olioeira, H.L. et al.: Pulmonary lesions produced by nephrotoxic anti-placenta senem. Int. Arch. Allergy., 20; 298, 1962.

2) Willoughby, W.F. \& Disxon, F. J.: Experimental hemorrhagic pneumonitis pnduced by heterologous anti-lung antibody. J. Immunol. 104; 28, 1970.

3) Kitamura, H.: Studies on oxperimental pneumonitis in rat induced by anti-rat-lung serum Acta Path. Jap., 22; 823, 1972.

4) Hagadorn, J.E., et al.: Immunopathologic studies of an experimental model resembling Good pasture's syndrome. Am. J. Path., 57; 17, 1969.

5) Yamaguchi, H. et al.: Studies on the morphological changes of antery caused by oxudation-initiol changes of astentis Acta Path. Jap., 22; 441, 1972.

1）暒川欽一郎；基底膜その形成と病的変化. 結合 織, 3; 7, 1971.

7) Comboe, J.H. et al.: Obygentoxicity. The effect of inhalation of high concentration of oeyan for 24 hous on normal men at se alevel 
ed a sirmleted alhith de of 18000 feet J. Am. Med. Ass., 128; 710, 1945.

[質疑】熊本大・病理 林秀男

（1）基底膜部位の electron density の増加は, なにか物質の沈着か, あるいは基底膜の collagen への移行か（基底膜に proline の多いこと から想像して）教示下さい.

（2）普通の血管透過性の充進にみられる電顕 像がないので, 実際に透過は充進しているの か, あるいは肺の細血管の透過像は他の組織血 管の透過像と異なるのか, 教示下さい.

\section{[応答]}

慶大・病理 鳥潟 親雄

(1) basement membrane の異常に高い elect- ron density の増加から, ある物質, 特に fibrin 様物質の diffuse な沈着の可能性はあるが同定 していない. 他の物質の沈着の可能性もあるが な拉，不詳である。

基底膜と collagen の関係は, 形態上は不明 である。

（2）肺に执いては，血管内皮間が gap を形 成して物質を透過することは, 非常に少いと思 われる. Pox と antipox rabbit serum の間に形 成した complex を投与し，DAB 反応でみた場 合も, pinocytotic vesicle K陽性物質がみられ るが gap を介して陽性物質が血管外に出る所 見は認めていない. 


\title{
出血傾向発現時における細静脈壁の変化
}

\author{
一一基底膜を中心に一-
}

重 信 雅 春* 木 村 穂 積*
大 本 武千代* 砂 田 輝 武*

外科臨床に抲いては, 出血という現象は常に 念頭におかねばならない問題であり，ときとし て出血傾向発現による皮下の点状出血や紫斑, 粘膜出血, 創部からのし文出るような出血 （oozing）飞遭遇し困惑することがある.

出血とは血液成分が血管腔内から血管外へ出 ることであるとするならば，血管因子をさぐる には，まず血球成分の血管壁通過の状態をなん らかの方法で観察検討することが不可欠である 々考学, 岡山大第 2 外科では, 光学顕微鏡, 16 $\mathrm{mm}$ 映画撮影, high speed camera $^{1)}$, 電子顕微 鏡2)を用いて腸間膜微小循環系に和ける実験的 漏出性出血の機序の解明に努力してきた。 その 結果, 出血に対する first barrier は endothelial junction であり, second barrier は basement membrane であることが確認されたが，さらに 基底膜を含む血管周囲基質が barrier として大 いに関与していることが推察されるので, これ らの物質を選択的に染色し電顕観察しらる方法 の開発の必要性が生じた。われわれの考案した 腸間膜平板包埋法 ${ }^{3)}$ に, ruthenium red による 染色法4) 導入し, 光顕および電顕観察した. 本法は, 基底膜および血管周囲基質に関する検 討にはすぐれた方法である。これにより，いさ さかの知見を得たので報告する。

\section{I. 実験方法}

nembutal で麻酔した雄成熟家鬼の腸間膜を, できるだけ生理的条件下に括くように配慮しな がら，透明なプラスチック製の観察台上に伸展 し, 光学顕微鏡で視野を選定した。

* 岡山大学医学部第二外科
出血傾向誘発の手段として, streptokinase を 使用した。採取した腸間膜標本は Epon の方 法により固定し, 脱水後, Epon 812 で平板包 埋した。

\section{II. 結 果}

\section{1. 対照群}

ruthenium red により，細静脈周囲の酸性粘 液多糖体が特異的に染色された。また，内皮細 胞間吵も染色されて括り, 同様の物質の存在が 考えられる。細静脈には, pericyte が多く, 数 層になって存在し，基底膜を介して吵間なく内 皮細胞を包んでいる。これに関連して, 酸性粘 液多糖体を成分とする基底膜が層を形成して， pericyte をとり囲んでいる像が得られた(図1).

\section{2. 出血傾向発現群}

出血傾向は細静脈領域に広範囲に誘発され， 赤血球は細静脈に沿って一面に散在している像 が観察された（図 2 ）。電顕観察によれば， 細 静脈の内皮細胞接合部は開大し, 赤血球が interendothelial gap に陥入しているのが認めら れた。 同時に tracer として耳静脈より $1 \mathrm{cc} / \mathrm{kg}$ 体重の割合で注入した墨汁粒子は，すでに血管 外へ大部分出ていた。興味ある所見として，生 理的条件下に扔いて連続性を保っている基底膜 が離断されて扣り，この部位から carbon tracer particle が出たことを想像させる。この離断部 は，丁度，基底膜が pericyte をとり囲むため に分岐する部位に一致していた（図 3 ）.

これまで基底膜を赤血球が通過している状態 を電子顕微鏡で観察したという報告はみられて いなかったが, ruthenium red で基底膜および 血管周囲基質を染色してみると, 赤血球があた 


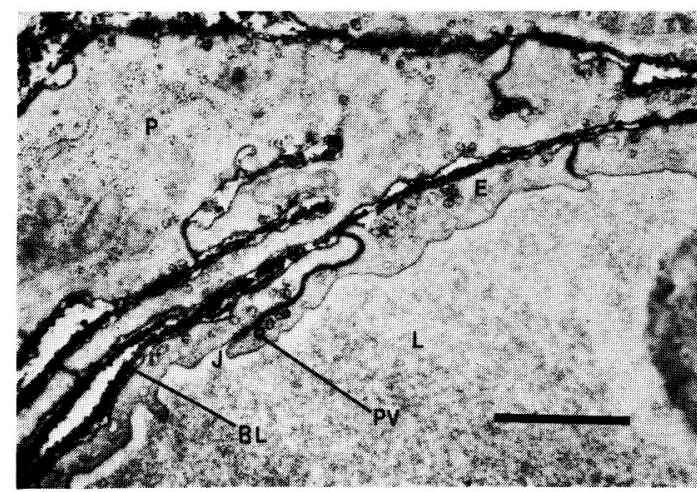

図 1 ruthenium red染色による細静脈血管壁像. $\mathrm{P}$ ：周皮細胞， $\mathrm{J}$ ：内皮細胞接合部, $\mathrm{E}$ ： 内皮細胞， $\mathrm{BL}$ : 基底膜層, $\mathrm{PV}$ : 貪食小胞, $\mathrm{L}$ ：血管内腔 (Scale は $1 \mu$ )

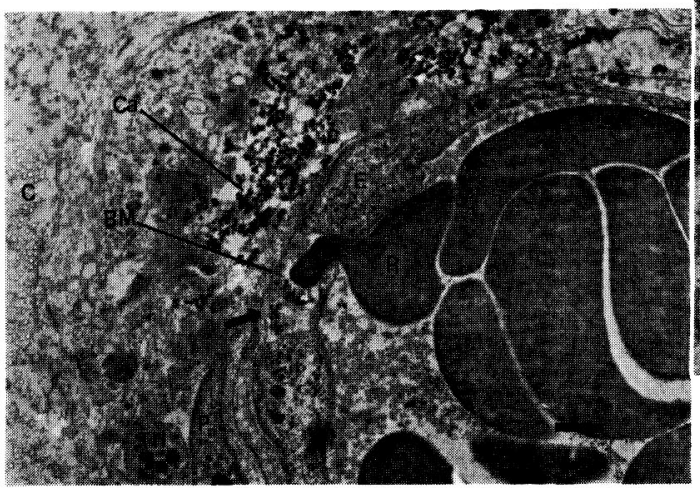

図 3 内皮細胞間隙に樎入した赤血球像。矢印 屾基底膜離断部。墨汁粒子はすでに大部分 血管腔外へ出ている。

$\mathrm{C}:$ 翏原線維, $\mathrm{Ca}$ : 墨汁粒子, $\mathrm{BM}$ : 基底膜 $\mathrm{TH}$ : 血小板,

かも偽足のような先進部をもって基底膜層を破 っている像が観察された（図4）。

\section{ま と め}

（1）腸間膜標本平板包埋法に ruthenium red による染色法を導入し, 微小血管の鮮明な光顕 像を得た。

（2）赤血球が基底膜のレベルで block されて いる像がしばしば喼められ, barrier としての 基底膜, さらに, その構成物質である酸性粘液 多糖体の重要性が示唆された。

（3）ruthenium red を使用して基底膜および

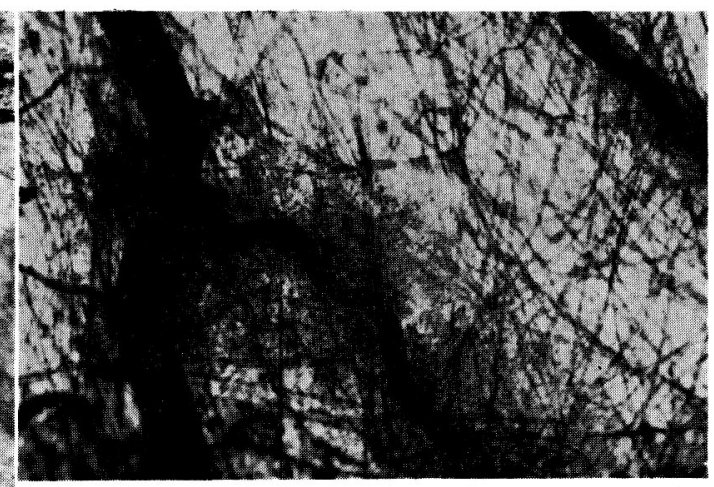

図 2 細静脈領域にみられる漏出性出血 $(\times 100)$

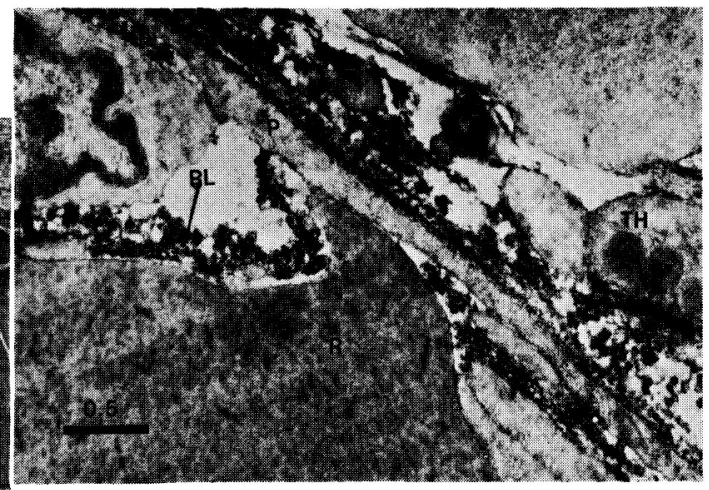

図 4 赤血球が，あたかも偽足のような先進部 をもって基底膜層を破っている像。 $\mathrm{R}$ : 赤血球 (Scale は $0.5 \mu$ )

血管周用基質を電子染色することにより，赤血 球が基底膜層を破っている像を観察した。

（4）血小板が基底膜層をつらぬいている像も 観察した。

\section{文献}

1) 島村幸夫 : 岡山医学会雑誌, 127, 1973.

2）大本武千代：岡山医学会雑誌， 78；1219, 1966.

3) 木村穂積 : 脈管学, 2；13，1973.

4) J.H. Luft: Fed. Proc. 25; 1773, 1966.

[啠疑]

慶大・病理 影山 圭三 漏出性出血はどのようにして生起されたか.

[応答］岡山大・第二外科 重信 雅春 （1）出血傾向誘発方法としては，先程も述べ 
ましたよらに，ストレプトキナーゼを耳静脈よ

り注入した。

（2）赤血球が血管壁を通過する状態をすでに フローリーが記載しているという点について.
われわれの研究の目的は, 赤血球の血管壁通過 時の基底膜の変化を知ることであり, 基底膜を 破って漏出する赤血球をとら光得たのは新知見 と考える。 


\section{-Session 2-}

\section{家鬼皮膚細血管の血管透過性に関する検討}

$$
\begin{array}{lllll}
\text { 河 合 誠一郎* 清 } & \text { 瀬 } & \text { 正 晴* } \\
\text { 小 山 士 郎* } & \text { 山田 外 春* }
\end{array}
$$

\section{はじめに}

プラスミンは血管の透過性を克進し紫斑を生 ずるとされる。この場合透過性充進がプラスミ ンの直接作用によるものか否かには問題がある が，いづれにしてもプラスミンの皮内注射で明 らかな局所の血管透過性克進は見られている。

われわれはこれに対し主として電子顕微鏡観 察を行なって 2,3 の所見を得たので報告する.

\section{I. 実験材料および方法}

実験材料には $3 \mathrm{~kg}$ 前後の白色雄性家鬼を用い Majno らの方法2)にしたがい家鬼陰囊皮つを使 用した。 プラスミンは人プラスミン（フイブリ ノリジンーミドリ)を用い, プラスミン生食溶 液 2.5c.u. (カゼイン単位) $0.1 \mathrm{ml}$ を 4 カ所に 皮内注射し 2 分, 5 分, 10 分, 20 分, と経時的 にその部位を切除して電顕標本を作成した。 tracer として含糖酸化鉄コロイドと, carbon コロイドを用い，各 $1 \mathrm{~m} l / \mathrm{kg}$ を皮内に注射直 後に混静注した。含糖酸化鉄は市販のフェジン （吉富）を用い, colloidal carbon 液は Perikan ink $\left(\mathrm{C}_{11} / 1431 \mathrm{a}\right)$ を用い, van Horn らの方法

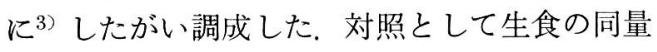
皮内注射を行ない，一方，ブラディキニン 0.01 $\mathrm{mg}$ 皮内注射の場合とも対比観察を行なった.

電顕組織の固定はオスミウム酸単独とグルタ アルデヒドオスミウム酸の二重固定とをあわせ 行ない型のごとくエポン包埋し, 酢酸ウラン, クエン酸鉛の二重染色をして観察した。

* 三重大学医学部第二内科

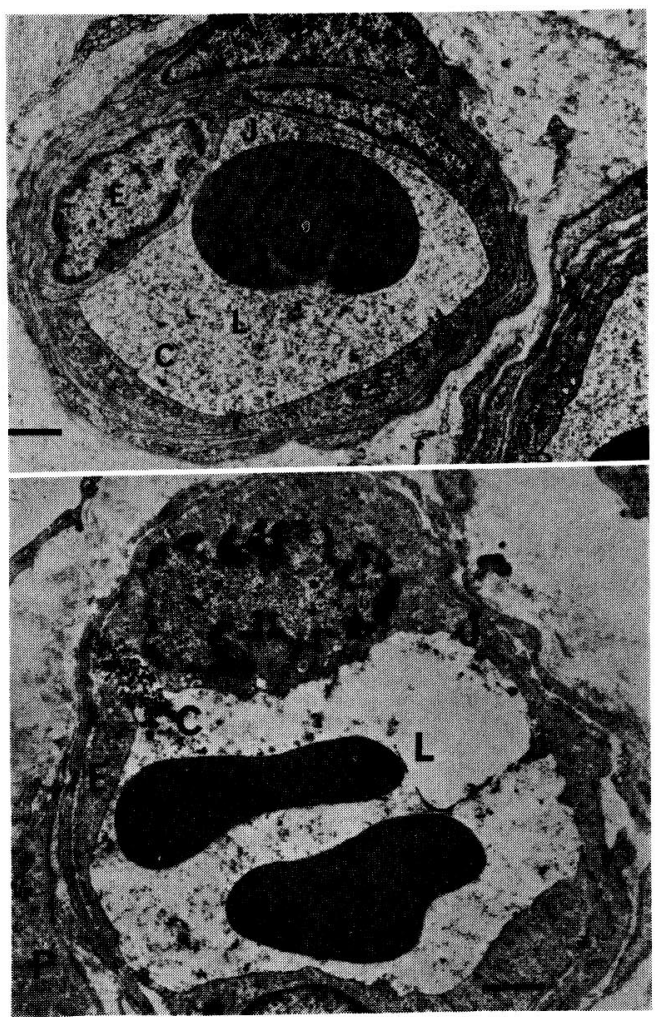

図 1 上: 生理的食塩水皮内注射 2 分後 下 : プラスミン皮内注射 2 分後

\section{II. 成 績}

刘称群の生理的食塩水皮内注射に打いてもま れに少量の Tracer の遊出が見られた.

プラスミンとブラデイキニンではいづれも著 明な Tracer の遊出が認められたが，この透過 が見られた血管は Chamber \& Zweifach の分 類 ${ }^{4)}$ による毛細血管から細静脈にいたる部分と 推定される部分である. 


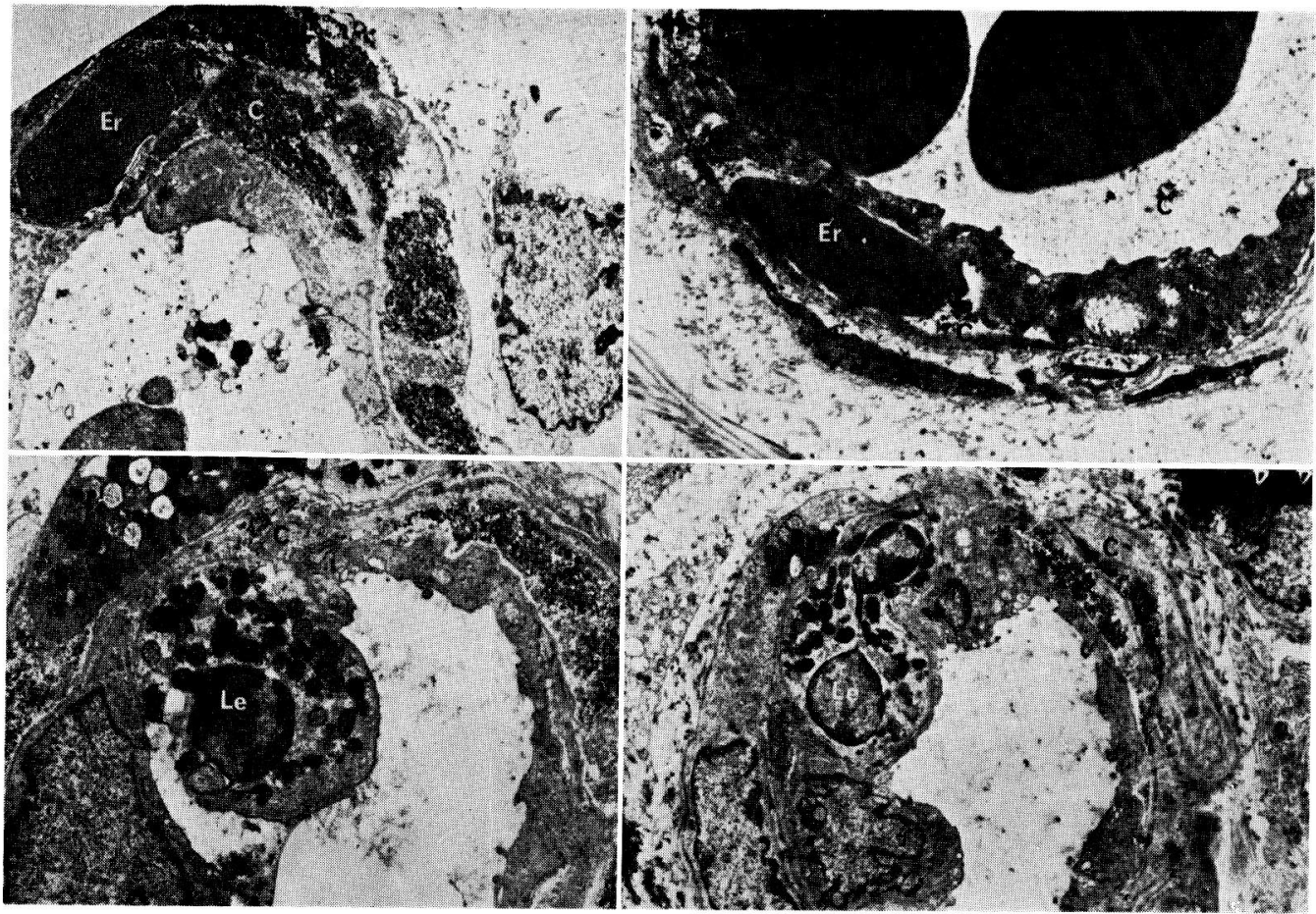

図 2
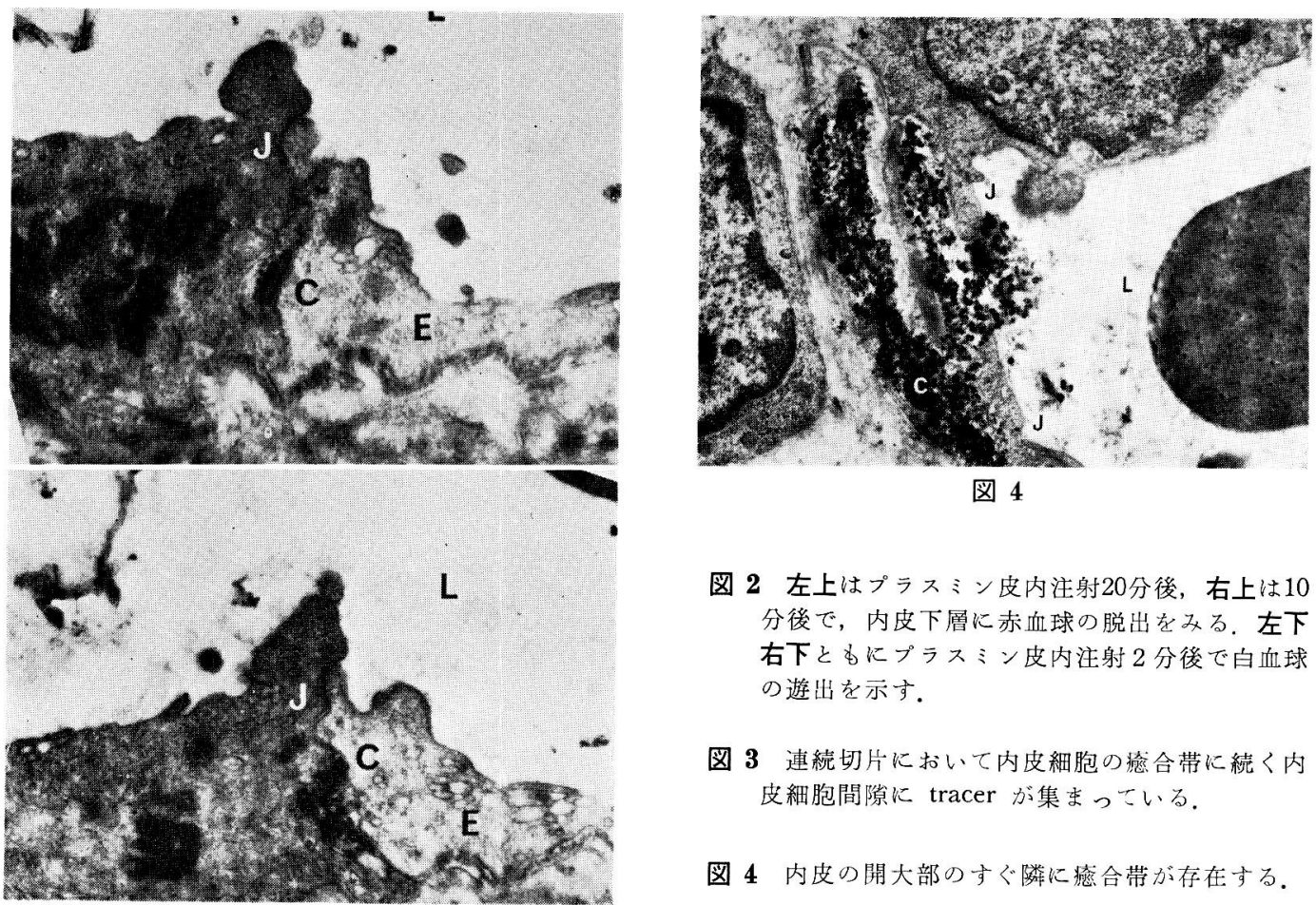

図 4

図 2 左上はプラスミン皮内注射 20 分後, 右上は 10 分後で，内皮下層に赤血球の脱出孝みる，左下 右下ともにプラスミン皮内注射 2 分後で白血球 の遊出を示す。

図 3 連続切片に打いて内皮細胞の癒合帯に続く内 皮細胞間陌に tracer が集まっている。

図 4 内皮の開大部のすぐ隣に㾤合帯が存在する。 
対称群に打ける生食皮内注射後 2 分のもの （図 1 上）では，4 カ所の内皮細胞接合部があ り, そのらちの 2 カ所で明らかに癒合帯を認め ることができるが内皮細胞接合部に tracer の 遊出は見られない。

これに対しプラスミン皮内注射 2 分後（図 1 下）に执いては，対称と比較して内皮細胞に形 態的変化は認められないが，内皮細胞核の近く にしばしば存在する内皮細胞接合部の位置で細 胞間が離開して tracer が透過している。この 場合 carbon 粒子とフェジン粒子が混在して細 胞の間隙を満たし血管内腔にもおよんでいる. 基底膜の lamina densa は対称群と比べ明らか な断裂を起こし，その外側にも tracer が沈着 している。 また tracer が沈着していない部位 の内皮下層にも膨化が見られるが，膨化のはな はだしいところは内皮細胞接合部に一致してい る傾向がある。

プラスミン皮内注射20分では（図 2 左上）血 管腔内の tracer は減少し, 内皮下層に脱出し た tracer は非常に濃縮され，均等に集まりそ れを除くと内皮下層の膨化は軽くなっている. この写真では内皮細胞間の開大は見られない が，この時間でも開大しているものもしばしば 見られる。

tracer うのち粒子の小さいフェジン粒子の 透過が carbon 粒子より遠くに扣よんでいる所 見は認められない．この所見は 2 分後でも同様 である（図4）。

tracer の逸脱と同じように白血球（図 2 下, 左右) や赤血球（図 2 上, 左右）が，時に栓球 が内皮下層に出ている.

図 1 下の写真で tracer の逸脱する部位が, 内皮細胞間隙ではないかと考光連続切片を切っ て観察をした. 図 3 は二枚の連続切片の写真で あるが，内皮細胞の癒合帯に続く内皮細胞間吵 の中に tracer が集まっている.

しかし内皮の開大部のすぐ隣に痖合帯がある ように思觉る所見にもしばしば接する（図4）.

\section{III. 考 按}

この実験に先だって行った Mils \& Mils 法に
よる Evans blue の青色斑はプラスミンでもブ ラディキニンと同様に出現した。 また対称とし た生理的食塩水でもごく薄い青色斑を示した が，電顕所見に执いてもまれに少量の tracer が血管内皮層から遊出している.

プラスミン処置後 tracer の逸脱する程度は 時間を経るにしたがい大量かつ広範となるとと もに血管腔の tracer はしだいに少くなる。プ ラスミン皮内注射 2 分後に tracer は内皮細胞 間隙を満たすよらに濃縮されて見られるが，こ れはすでに血漿成分と一諸に tracer が透過し, tracer だけが濃縮されて残ったものだろう。

プラスミン皮内注射20分後に内皮下層に脱出 した tracer は非常に濃縮され均等に集まって それを除くと内皮下層の膨化は軽くなってい る.すすおち透過のピークはすでに過ぎている のであろう。 tracer と一諸に大量の血漿が血 管外に出るのに際し, 基底膜, pericyte がふる いの役割をして tracer のみが濃縮して残った ものと考えられる.

tracer の大小によって透過の態度に質的ま たは量的な差があると考䒚てフェジンと colloidal carbon の両者を同時に用いたが，粒 子の小さいフェジンも carbon と同様細胞間吵 を通過し遊出の程度にも差を認めなかった。

tracer の逸脱する部位については図 3 の連 続写真に扔いて内皮細胞の癒合帯につづく内皮 細胞間吵の中に tracer の一塊が見られるのは どの部位で血管腔から出てきたのか, 癒合帯が 開いて入ったのか，またはこれらの切断面以外 で細胞間吵から入ったとも思われ，いづれとも 決しかねる。 もし内皮細胞接合部がすべて癒合 帯で接着しているとすればそこが開いたとしか 考兄られない，なぜ内皮細胞接合部のらちごく 限られたところしか開かないのかという疑問が 生ずる。図 4 に示したよらな内皮細胞の離開し た部位のすぐ隣に癒合帯があるように見觉る所 見は $\mathrm{Majno}^{2)}$ らも指適しているものであって しばしば認められた。 またまれにきわめて近接 して2つの内皮細胞開大があり，その中間にも 内皮細胞の小部分が見られるといら像にも接す る.これらの所見から， 3 個の内皮細胞が接す 
る部分から漏れ出しやすいのではないかとも推 量できる。

今後の問題は内皮細胞接合部が㾳合帯ばかり でなく，その存在しないところがあるのではな いか検討することと，3個の内皮細胞が接して いる部分で tracer の脱出が起こりやすいのか連 続切片でさらに検討することが必要であろう。

\section{文献}

1）木村義民: Medical Digest 10；8，1971.

2) Majus, G., Polade, G.E.: J. biochys. biochem. 11; 571, 1961.

3) cytol., nan Horn, D.L. \& Johnson, S.A.: Am. J. Clin. path., 96; 204, 1966.
4) Chamber, R., Zweifach, B.W.: Am'. J. Anat 75; 173, 1944.

〔質疑〕九大・病理 黒住 武史 先生が引用される tight junction とは Zonula occludens といわれるものの中で, truely tight junction であるのか, あるいは gap junction と いわれているものであるのか。いずれか.

[応答］ 三重大・第二内科 河合誠一郎 皮フの毛細血管から細静脈に叔ける内皮細胞 結合部が gap junction であれば，血管透過性 光進時そこから tracer が出るといいやすいが 今後さらに検討を行ないたい. 


\title{
- Session 2-
}

\section{ラット腎血管傷害因子の細胞内局在}

\author{
村 山一子”住吉昭 信”内藤 説 也* \\ 加 藤 敬太郎* 中 村 元 臣 ${ }^{*}$
}

腎ホモジネートに血管傷害を誘発する因子が

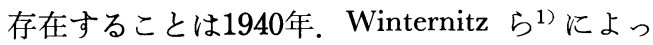
て報告されて以来, 多くの研究が行なわれてき た。両側腎摘出動物に腎抽出液を負荷すると, 血管透過性の立進が起こり, 胸水, 腹水が貯留 し，あるいは血漿蛋白の漏出が起こる，また肺 や，他の器管の水腫，血管壊死等が起こるとさ れている ${ }^{2 \sim 9)}$. したがって腎抽出液中に血管透 過性を充進させたり，血管傷害をひき起こす物 質の存在が示唆されている。しかし，いまだそ れらの物質は単離されていない，近年その物質 の細胞内局在に関していくつかの研究がみられ る，それらはリソゾーム分画にあるとする成績 とミクロゾーム分画にあるとする成績とに分か れている ${ }^{6,8)}$. 腎抽出液にはレニンが含まれ， それは血圧を上昇させ，水摂取量を増加させる ため，これら血管透過性の立進や血管傷害を起 こす物質はレニンであろらとする考方方があ る。われわれはこれら従来の成績の混乱の原因 の 1 つに僌密な精製が行なわれていないことが あげられると考觉まず細胞内顆粒をより純度の 高い画分に分離し，その物質の細胞内局在を明 らかにすることを目的に今回の実験を行なっ た。

\section{I. 実験材料および方法}

Wistar 系正常ラット雄（200～250g）の腎皮 質を Shibko \& Tappel の方法 ${ }^{1()}$ に準じて，核 ミトコンドリア・リソン゙ーム (Mt-Ly), ミク ロゾーム (Ms)，上清（Sup）に分画した。さ らに, Mt-Ly を低張庶糖溶液で処理すること

* 九州大学医学部循環器内科, 病理, 生理

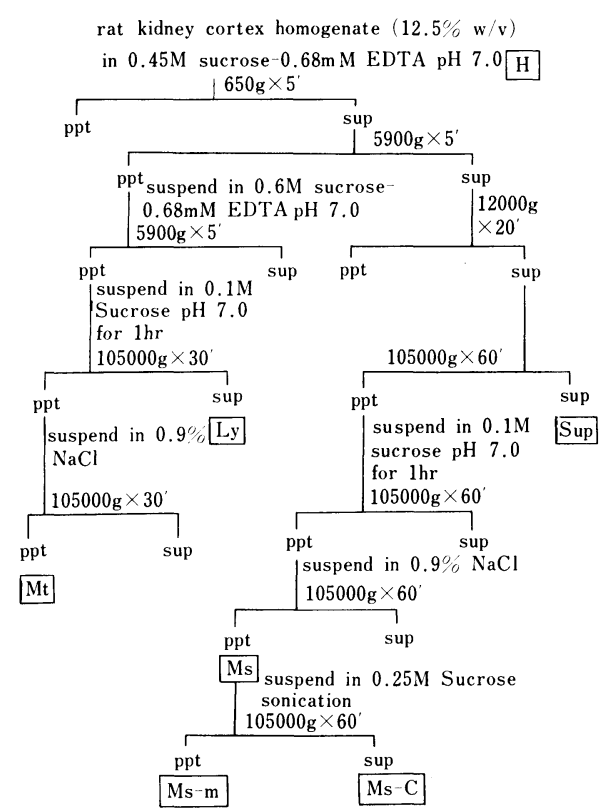

図 1

により，Ly の内容物を分離した。 Ms 分画に ついては，他の夾雑物をできるだけ除くため， 低張庶糖溶液で処理した沈殿を塩溶 液で洗っ た（図 1 ）。このようにして得られた各分画に ついて，扣の拈のの顆粒分画に特徵的な酵素を 測定して，精製純度の検定を行なった。 また， 各分画のレニン活性を Conradi ら ${ }^{11)}$ の方法で 測定した。蛋白濃度は Lowry 法 ${ }^{12}$ で測 定 し た.

次に得られた各分画を用いて，1) Evans blue 法で家鬼皮膚の血管透過性元進作用の存否を肉 眼的に検定し，2）両側腎摘出ラットを用いて 血管傷害作用，および，その他の变化を組織形 
表 1 各分画の酵素比活性

\begin{tabular}{|c|c|c|c|c|c|}
\hline $\begin{array}{ll}\text { Enzyme } & \text { Fraction } \\
\text { Enzen }\end{array}$ & $\mathrm{H}$ & Mt & Ly & Ms & Sup \\
\hline Acid phosphatase $\dagger$ & 58 & 96 & 387 & 78 & 47 \\
\hline$\beta$-Glucuronidase $\dagger$ & 1. 6 & 1. 8 & 12. 7 & 0.7 & 1. 4 \\
\hline $\begin{array}{l}\text { cytochrome oxid- } \\
\text { asse }\left(\times 10^{-2}\right)\end{array}$ & 5 & 23 & 0.03 & 3 & 0.1 \\
\hline $\begin{array}{l}\text { Succinic cytochr- } \\
\text { ome C reductase } \\
\left(\times 10^{-2}\right)\end{array}$ & 6 & 34 & 0.18 & 0.9 & 0.08 \\
\hline $\begin{array}{l}\text { Glucose-6-phosp- } \\
\text { hatase }\end{array}$ & 47 & 8 & 0 & 267 & 10 \\
\hline renin $\quad t \dagger \dagger$ & 468 & 146 & 3417 & $\begin{array}{r}0(3 / 6) \\
61(3 / 6)\end{array}$ & 406 \\
\hline
\end{tabular}

単位 $\dagger: \mathrm{m} \mu \mathrm{mole} / \mathrm{min} / \mathrm{mg}$ 蛋白

计: $\Delta \log$ Ferricytochrome $\mathrm{C} / \mathrm{min} / \mathrm{ng}$ 蛋白

计 : $\mathrm{ng} / \mathrm{min} / \mathrm{mg}$ 蛋白（数值は平均值を示す）

態学的に検索した.

\section{II. 結 果}

\section{1. 各分画の純度の検定}

各分画に特徵的な酵素として Mt 分画では, Cytoc rome oxidase, Succinic cytochrome $\mathrm{C}$ reductase, Ly 分画では Acid phosphatase, $\beta$ Glucuronidase, Ms 分画では Glucose-6-phosphatase を選び，レニン活性とともに測定した ところ，表 1 に示すような結果を得た。すなわ ち, Ly 分画では Acid phosphatase, $\beta$-Glucuro nidase 活性は単位蛋白 $\mathrm{mg}$ あたり, ホモジネ ート $(\mathrm{H})$ の約 $6 \sim 8$ 倍高く, Mt の酵素と考 えられる Cytochrome oxidase や, Succinic cytochrome C reductase はH $\mathrm{H} 1 \sim 3 \%, \mathrm{Mt}$ の0.1 0.6\% と極度に低い，また，Ms 分画も Glucose-6-phosphatase でみた場合，Hの約 5 倍の標品が得られた。 レニン活性については, Ly 分画でもっとも高く, Ms 分画では 6 回の 標品調製のらち 3 回で昇圧活性は 0 で, 残り 3 回では平均 $61 \mathrm{ng} / \mathrm{mg}$ 蛋白を示した。 したがっ てレニン活性からみると, Ms 分画へ Ly 顆粒 の混入はきわめて少ないと考兄られる。

\section{2. 家兔皮膚血管透過性穴進}

家鬼に Evans blue を静注し，腹部皮虐に， 先に得られた各標品を $0.1 \mathrm{ml}$ (蛋白量で 0.1 $0.2 \mathrm{mg}$ 相当を原則とした）ずつ，皮内注射し て血管透過性立進の有無を調べた。その結果, 表 2 に示すごとく, Ly 分画と Ms 分画に透過 性六進がみられた。 Ms 分画では Ms の内容物 (Ms-c)に活性が高く, Ms の膜分画 (Ms-m) に低いように思われた。 Ly 分画は投与後, 5 〜15分で最高の透過性穴進を示したが，Ms 分 画は投与後, 40 ～60分で最高の活性を示した. また予め, 抗ヒスタミン剤 (ポララミン $20 \mathrm{mg}$ / $\mathrm{kg}$ ）を静注した家鬼では，Ly分画の皮膚血管 透過性克進作用は抑制されたが，Ms 分画のそ れはほとんど抑制されなかった，Ly 分画で $0.02 \mathrm{mg}$ 蛋白相当, Ms分画で $1 \mathrm{mg}, 2 \mathrm{mg}$ 蛋白 相当で $0.1 \mathrm{~m} l$ 溶液とし, 同様の実験を行なって も，結果は原則的には同じであった．Mt 分画 も，Sup 分画もであったが，Mt 分画は Ly 顆

表 2 各分画の血管透過性立進作用

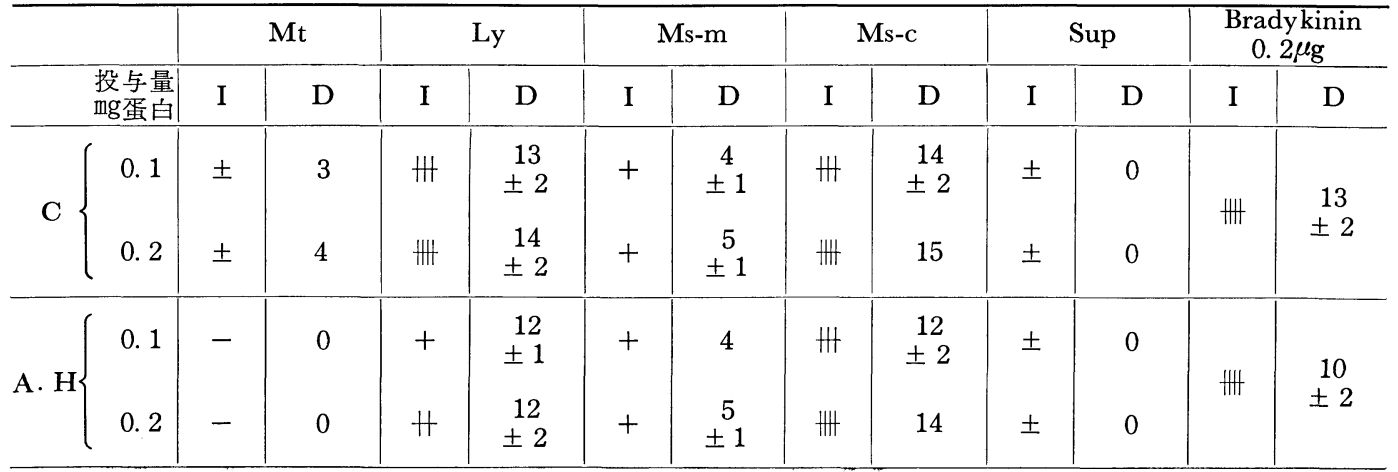

C : Control A.H. : Antihistamide (ポラミン $20 \mathrm{mg} / \mathrm{kg}$ )

I : intensity $-\sim$ HI, D : Diameter $(\mathrm{mm})$ (平均 \pm S.D.) 
表 3 各分画投与による腹水, 胸水の貯留及び血管病変

\begin{tabular}{c|c|c|c|c|c}
\hline & $\begin{array}{c}\text { mg } \\
\text { prote- } \\
\text { in }\end{array}$ & $\begin{array}{c}\text { No } \\
\text { of } \\
\text { rats }\end{array}$ & $\begin{array}{c}\text { Ascitic fluid } \\
\text { (ml/rat) }\end{array}$ & $\begin{array}{c}\text { Pleural effus- } \\
\text { ion (ml/rat) }\end{array}$ & $\begin{array}{c}\text { vascular } \\
\text { lesion }\end{array}$ \\
\hline \multirow{2}{*}{ Ly } & 3 & 5 & 1.0 & 2.5 & $+\sim H$ \\
\cline { 2 - 6 } & 6 & 8 & 1.4 & 3.5 & H $\sim+1$ \\
\hline \multirow{3}{*}{ Ms } & 6 & 5 & 0 & 0 & - \\
\cline { 2 - 6 } & 60 & 9 & 0.7 & 1.5 & $-\sim+$ \\
\hline \multirow{2}{*}{ Ms-m } & 60 & 8 & 0.9 & 2.0 & $-\sim+$ \\
\hline \multirow{3}{*}{ Ms-c } & 9 & 2 & 0 & 0.3 & $-\sim+$ \\
\cline { 2 - 6 } & 34 & 3 & 1.1 & 1.2 & - \\
\hline
\end{tabular}

粒が混入しているためであり, Sup 分画もまた リソゾーム顆粒の自己融解による混入のためと 考光られた。

\section{3. 両側腎摘出ラットへの影響}

Wistar 系正常ラット雄 $(150 \sim 200 \mathrm{~g})$ を両側 腎摘出し， 6 時間後各分画を腹腔内に $3 \mathrm{~m} l$ 注射 した。腎摘出後, 24 時間経過した時点で屠殺 し，剖検した。表 3 に示したごとく，Ly 分画 $3 \mathrm{mg}$ 竹よび $6 \mathrm{mg}$ 蛋白投与により, 腹水, 胸 水の貯留が認められた。 Ms 分画は $6 \mathrm{mg}$ 投与 群では腹水，胸水とも認められなかったが，60 $\mathrm{mg}$ 投与群では貯留が認められた。 Ms 分画を 膜分画と内容物に分けた場合，相方とも有意の 差はみとめられなかった。 また，Ly 投与群お。 よび Ms 大量投与群ではしばしば 形態学的に 肺水腫が認められた，血管の類線維 素変性は 分画投与群では膵忬よび腸間膜の主として小細 動脈（十〜Hの程度）に認められた（図 2,5, 表 3 )。 また, 冠状動脈の前下行枝分枝にも 1 例, 類線維素変性がみられた。 これらの変化 は，Ly 分画を静注しても，また腎摘していな いHRS ラットに腹腔内注射しても認められ た。しかし，Ms 分画投与群では27例中， 4 例 に膵就よび腸間膜の小細動脈に軽度 $(+)$ の病 変を認めたにとどまった（表 3 ）。 また抗ヒス タミン剂を予め投与したラットに Ly 分画を負 荷した場合, 胸水, 腹水の貯留量には顕著な抑 制はみられなかった， Mt 分画やSup 分画は 1 例も腹水をきたさず，稀に胸水をみとめたに

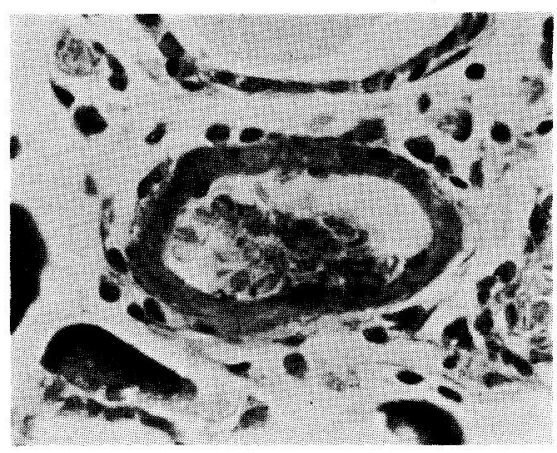

図 2 リソゾーム分画内容物 $6 \mathrm{mg}$ 腹腔内注 射膵小動脈（PAS 染色，740倍）

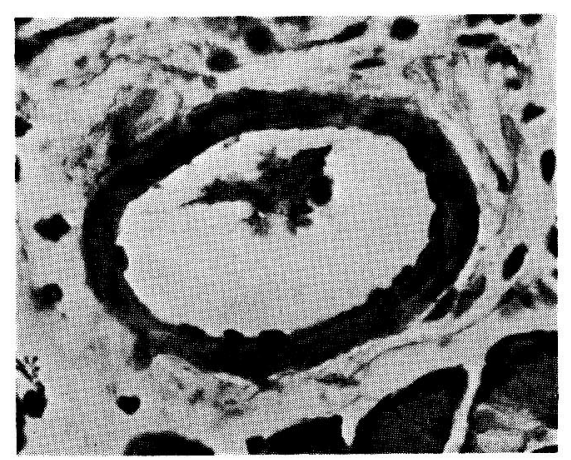

图 3 リソゾーム分画内容物 $6 \mathrm{mg}$ 静脈注射 膵小動脈 (PAS 築色, 740倍)

止まった。

\section{III. 考 按}

Evans blue 法による家鬼皮膚血管透過性を 亢進させる物質が、ラット腎皮質より調製した Ly 分画と Ms 分画に存在することが明らかに なった．Ly 分画では0.02〜0.2mg 蛋白を用い た範囲で，抗ヒスタミン剤の前処置によって家 鬼皮虐血管透過性元進作用の抑制が認められる が，Ms 分画は 0.1〜2mg の範囲で検討した限 り, 皮膚血管透過性元進の抑制が認められなか った．このことから，Ms 分画の皮膚血管透過 性直進作用は Ly 分画の混入によって表われた とは考壳にくい，したがって，Ly 分画と Ms 分画には家躳皮膚血管透過性を直進させる物質 が別々に存在する可能性が示唆された。

また両側腎摘出ラットにラット腎皮質分画を 負荷した場合, Ly 分画は $3 \sim 6 \mathrm{mg}$ 蛋白相当量 
で腹水，胸水の貯留を起こしたが， Ms 分画は $6 \mathrm{mg}$ 蛋白相当量では起こさず, $34 \mathrm{mg}, 60 \mathrm{mg}$ という大量投与で始めて起こした。 またこの場 合, 抗ヒスタミン剂は顕著な抑制を示さなかっ た。したがって皮膚血管透過性元進と, 腹水, 胸水の透過性立進とが常に同一の作用を示して いるとは断定し得ないように思われた。ささら 本研究で得た Ly 分画は脺および腸間膜の主に 小, 細動脈に類線維素変性を誘発したが，レニ ン活性を高濃度に含有しているために、レニン によりこれらの病変が起こったのか, レニン以 外の物質によったのか, 今後の検討を必要とす る. また， Ms 分画は投与したラットのごく一 部にのみ，Ly 分画投与結果と質的に 差がない 類線維素変性を起こしたこと, 大量投与によっ て始めて, 腹水, 胸水の貯留, 肺水腫を起こし たことが特徵的であった。

\section{文 献}

1) Winternitz, M.C., Mylon, E. Wzaters, L.L. and Katzenstein, R.: Yale, J. Biol. \& Med., 16; $623,1940$.

2) Nairn, R.C., Masson, G.M.C. and Corcoran, A.C.: J. Path. Bact., 71; 155, 1956.

3) Cuthbert, M.F. Assher, A.W. and Jones, H.: Clin. Sci., 31; 325, 196.

4) Giese, J.: Acta path. Microbiol. Scand., 56; 399, 196.

5) Omae, T. Hattori, N., Iwata, Y., Tamka,K., Tanaka, K. and Katsuki, S.: Am. Heart J., 75; 76, 1968.

6) Shinomura, A.: Acta Medica Nagasakiensia 15; 58, 1971.

7) Namba, S., Hiramatsu, Y., Kusunoki, F., Okuda, K.: and Sokabe, H.: Jap. Circ. 32; $1585,1968$.

8) Kira, J., Saito, N., Matsunaga, M., Ogino, K. and Takayasu, M.: Jap. Circ. J., 32; 1, 1968.

9) Vaughan, Cavras, Laragh and Koss Nature, 242; 334, 1965.

10) Shibko, S. and Tappel, A.L.: Biochem. J., 95; 731, 1965.

11) Conradi, K., Jelinek, J. and Gross, F.: Proc. Soc. exp. Biol. Med., 132, 984, 1969.
12) Lowry, O.H., Rosebrough, N.J., Farr, A.L. and Randall, R.J.: J. Biol. Chem., 193, 265 1951.

\section{[質疑]}

熊本大・病理 林秀男

(1) Lysosome の透過因子は抗ヒスタミンで 抑制されるとすれば，この分画による血管壊死 効果は別の因子ではないかと考えられるが，こ の因子は enzyme か, 熱効果はいかがか.

(2) Microsome の透過因子は抗ヒスタミンに 抵抗するが，血管壊死を括こさないので，従来 の透過因子との比較はいかがか.

[応答]九大・循環器内科 村山一子

（1）熱変性した Ly 分画を用いて家兔皮膚血 管透過性元進作用をみてみますと, 透過性元進 はなくなります，両側腎摘ラットについての影 響はまだみていない。

（2）Ms 分画にはいわゆる 血管透過性六進作 用がある, Ms 分画にも血管壊死が27例中 4 例 みられたため，注んとうに血管壊死作用がない かどらか今後検討する必要があると思われる。

（Ms 分画をレニン活性がまったくない状態に 精製分離して血管壊死が起きるかどうか調べる 必要がある.)

〔追加〕信州大・生理 東 健彦 形態学的所見から透過性を論ずる場合，手技 上の困難はあると思らが生理的内圧負荷のもと で標本を作製することが望ましい.

[追加]慶大・病理 影山 圭三 血管透過性の問題を形態学的手法で追求する ために, さらに delicate な sense で, 電顕標本 を作製することを期待しますし， tracer につ いてもさらに充分な配慮が望ましい。たとえ ば, Horse radish peroxydase を用いた。電顕的 免疫酵素組織化学的手法を導入するのも一法で あろらと考光る。

これらによって，さらに明確に問題が整理さ れることを希望する。

［追加］阪大・蛋白質研究所 鈴木 友二 
座長の影山先生の“より実証的な方向へ”と いら意見で結ばれた考光に追加してですが， 5 席の研究については, 私はプラスミンの色素漏 出作用はブラディキニンによるといら結論に近 いものとらけとられました。そうだとするとブ
ラディキニンの作用を特異的に強めるブラディ キニン作用増強物質のペプチドが活用できる現 況ですから，こらした日本で使える物質を併用 して生化学的な面からの実証の一面を示すこと も可能かと考光る. 